Anais da Academia Brasileira de Ciências (2006) 78(3): 543-556

(Annals of the Brazilian Academy of Sciences)

ISSN 0001-3765

www.scielo.br/aabc

\title{
The Glória quartz-monzodiorite: isotopic and chemical evidence of arc-related magmatism in the central part of the paleoproterozoic Mineiro belt, Minas Gerais State, Brazil
}

\author{
CIRO A. ÁVILA ${ }^{1}$, WILSON TEIXEIRA ${ }^{2}$, UMBERTO G. CORDANI ${ }^{2}$, HÉCTOR R. BARRUETO ${ }^{1}$, \\ RONALDO M. PEREIRA ${ }^{3}$, VERIDIANA T.S. MARTINS ${ }^{2}$ and LIU DUNYI ${ }^{4}$ \\ ${ }^{1}$ Departamento de Geologia e Paleontologia, Museu Nacional, Universidade Federal do Rio de Janeiro \\ Quinta da Boa Vista, São Cristóvão, 20940-040 Rio de Janeiro, RJ, Brasil \\ ${ }^{2}$ Centro de Pesquisas Geocronológicas, Instituto de Geociências, Universidade de São Paulo \\ Rua do Lago 562, Cidade Universitária, 05508-080 São Paulo, SP, Brasil \\ ${ }^{3}$ Departamento de Geologia Aplicada, Faculdade de Geologia, Universidade do Estado do Rio de Janeiro \\ Rua São Francisco Xavier 524 sala 2019A, Maracanã, 20540-900 Rio de Janeiro, RJ, Brasil \\ ${ }^{4}$ Institute of Geology, Chinese Academy of Geological Sciences \\ Beijing, China, Baiwanzhuang Road 26, Beijing 100037 China \\ Manuscript received on November 22, 2005; accepted for publication on January 30, 2006; \\ contributed by UMBERTO G. CORDANI* AND WILSON TEIXEIRA*
}

\begin{abstract}
The Glória quartz-monzodiorite, one of the mafic plutons of the Paleoproterozoic Mineiro belt, is intrusive into banded gneisses, amphibolites, schists and phyllites of the Rio das Mortes greenstone belt, in the southern portion of the São Francisco Craton, State of Minas Gerais, Brazil. The Glória quartz-monzodiorite yields a SHRIMP U-Pb zircon age of $2188 \pm 29 \mathrm{Ma}$, suggesting a tectonic relationship with the pre-collisional phase of the Mineiro belt. According to the $\mathrm{Nd}$ isotopic evidence $\left(\varepsilon_{\mathrm{Nd}(\mathrm{T})}=-3.4 ; \mathrm{T}_{\mathrm{DM}}=2.68 \mathrm{Ga}\right)$ the original magmas was formed by a mixture among Archean crustal material and Paleoproterozoic juvenile magma. The Glória quartz-monzodiorite shows metaluminous and calc-alkaline tendency with intermediate $\mathrm{K}$ content, comparable to that of volcanic-arc rocks. The primary mineralogical assemblage was partly modified by metamorphism, dated between 2131-2121 Ma in nearby coeval plutons. Such metamorphism is significantly older than the reported metamorphic episodes of the Mineiro belt in the Quadrilátero Ferrífero region (2059-2041 Ma) in the eastern portion of the study area. This evidence, together with chemical and isotopic data from other mafic and felsic plutons coeval with the Glória quartz-monzodiorite, indicate a tectonic and magmatic migration within the Mineiro belt from west to east.
\end{abstract}

Key words: Glória quartz-monzodiorite, U-Pb SHRIMP, Sm-Nd isotopes, Mineiro belt, São Francisco Craton.

\section{INTRODUCTION AND REGIONAL GEOLOGY}

The geological framework of the southern border of the São Francisco Craton comprises Archean and

\footnotetext{
*Member Academia Brasileira de Ciências Correspondence to: Ciro Alexandre Ávila

E-mail: avila@mn.ufrj.br
}

Proterozoic lithotectonic units of varied age and nature, which are now exposed side by side in response to multiple magmatic, tectonic and erosional processes (Figure 1). Such a framework can be summarized as follows: i) an Archean crust composed mainly of granulites and partly migmatized 
gneisses (Campo Belo, Bonfim, Passa Tempo and Belo Horizonte complexes) and greenstone belt remnants (e.g., Rio das Velhas Supergroup in the Quadrilátero Ferrífero region) further intruded by Archean felsic plutons; ii) a Paleoproterozoic terrane occurring along the southern edge of the craton, containing the Rio das Mortes and Nazareno greenstone belts, as well as voluminous mafic and felsic plutonic intrusions; and iii) Proterozoic supracrustal sequences of different ages (Minas Supergroup, and São João del Rei, Carandaí and Andrelândia megasequences).

The Paleoproterozoic plutons constitute most of the Proterozoic terrane and are genetically associated with the pre-, syn- and late-tectonic stages of the Mineiro belt (Noce et al. 2000, Teixeira et al. 2000). In addition, these plutons exhibit Nd$\mathrm{Sr}$ isotopic characteristics and calc-alkaline affinities that are compatible with products evolved from accretionary arc settings (e.g., Noce et al. 2000, Quéméneur and Noce 2000, Teixeira et al. 2005).

Recent geological mapping carried out in the central part of the Mineiro belt between Lavras and Conselheiro Lafaiete regions (see Fig. 1) has shown that the mafic and ultramafic rocks formally related with the Barbacena greenstone belt can be assigned to two separated tectonic-stratigraphic units - the Nazareno and Rio das Mortes belts (Ávila et al. 2004). The mafic and ultramafic rocks of both belts were overprinted by two successive deformational and metamorphic events. The first one reached lowto medium-grade amphibolite facies, whereas the second developed under greenschist- to low- amphibolite facies. The latter episode also overprinted the neighboring mafic and felsic plutons of the Mineiro belt (C.A. Ávila, unpublished data).

The present work deals with the magmatic evolution of the Glória quartz-monzodiorite, as supported by isotopic and chemical studies, addressing new insights on its tectonic significance. Moreover, the new isotopic (Sm-Nd) and geochronological (SHRIMP U-Pb zircon) data of the Glória pluton are compared with those of contemporary plutonic bodies to better understand the Paleoprote- rozoic evolution of the central part of the Mineiro belt, in the southern edge of the São Francisco Craton.

\section{GLÓRIA QUARTZ-MONZODIORITE - GEOLOGY AND PETROGRAPHY}

The Glória quartz-monzodiorite occurs between Ritápolis and Coronel Xavier Chaves, underlying an area of $9 \mathrm{~km}^{2}$ (Figure 2). It shows a NNE/SSW trending foliation and is emplaced into banded gneisses, amphibolites, schists and pelites of the Rio das Mortes greenstone belt. The body, as well as the nearby coeval intrusions (Brumado and Rio Grande diorites), displays amphibolite and pyroxenite xenoliths that resemble, respectively, the typical lithologies of the Rio das Mortes greenstone belt and the pyroxenitic-gabbroic bodies that crop out in the vicinities (Ávila et al. 1999).

The Glória rock specimens are usually isotropic, and comprise three different petrographic facies based mainly on grain size, that varies between 0.1 and $4.0 \mathrm{~mm}$. The relatively older fine-grained facies $(\mathrm{F})$ has a restricted distribution and is usually sectioned sharply by the common fine/medium grained facies (FM). The youngest medium grained facies (M) occurs mainly as apophyses and displaying sharp contacts with the other facies (Ávila et al. 2004). In addition, quartz-feldspathic aplites, quartz- and epidote-bearing veins, granitic dykes and pegmatitic injections cut randomly the Glória quartz-monzodiorite as well as the adjacent mafic bodies (e.g., Brumado diorite). These felsic intrusions are coeval with the Ritápolis granitoid (2121 $\pm 7 \mathrm{Ma}-$ C.A. Ávila, unpublished data) that crops out extensively in the northwest part of the studied area.

Plagioclase, amphibole, biotite, quartz, Kfeldspar, titanite and epidote compose the primary and metamorphic mineralogies of the Glória pluton. The primary texture of the minerals is dominantly equigranular, with predominant hypidiomorphic plagioclase crystals and subordinately intergranular quartz. Modal compositions are characteristic of quartz-diorite, quartz-monzodiorite and tonalite 


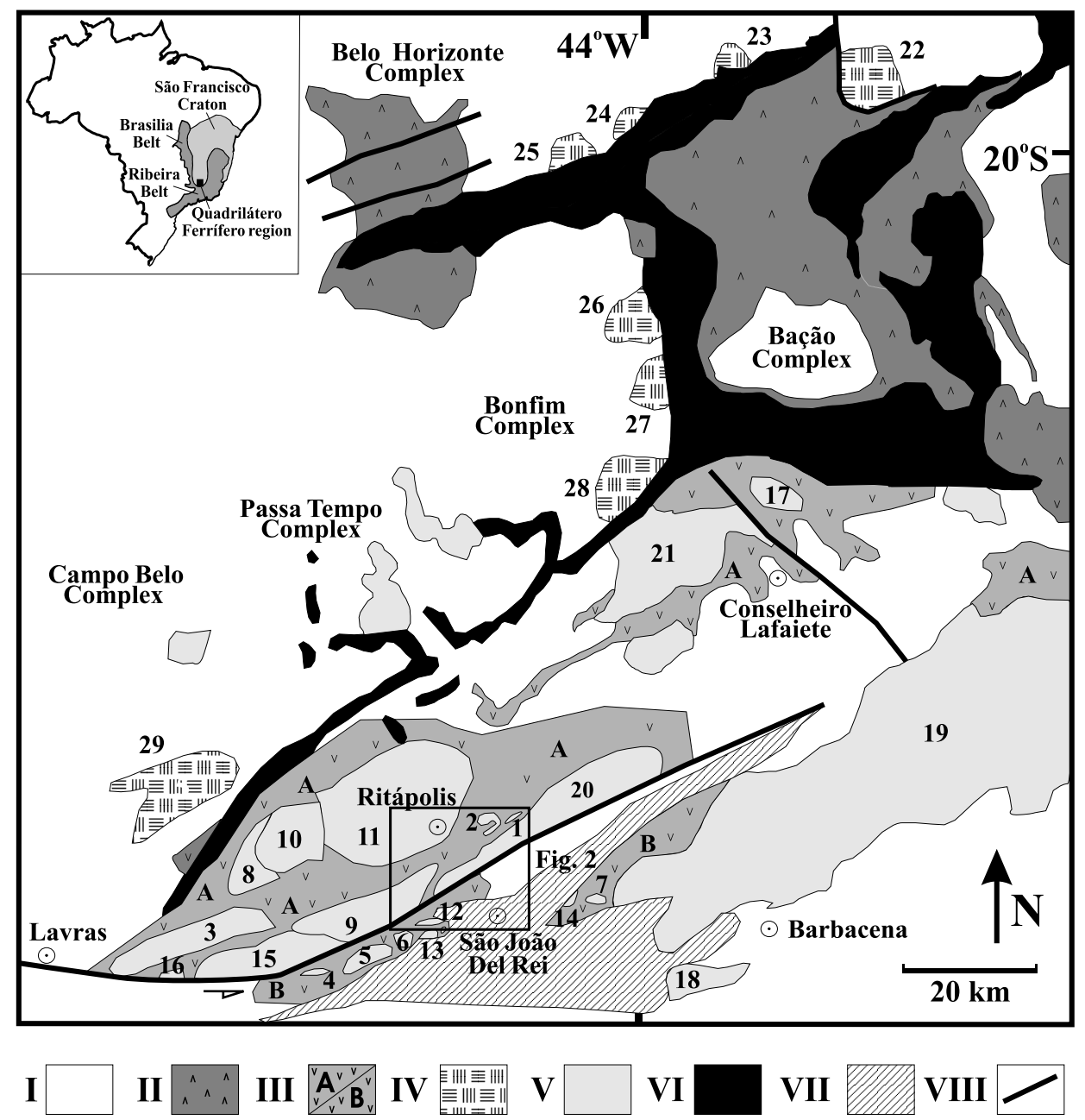

Fig. 1 - Archean and Paleoproterozoic plutons in the southern São Francisco Craton (adapted from Ávila et al. 2003). I- Archean crust partly reworked during Paleoproterozoic times. II - Archean Rio das Velhas greenstone belt. III - Rio das Mortes (A) and Nazareno (B) greenstone belts. IV - Archean granitoids. V - Paleoproterozoic felsic and mafic plutons VI - Minas Supergroup (Paleoproterozoic). VII - São João del Rei (Paleoproterozoic), Carandaí (Mesoproterozoic) and Andrelândia (Neoproterozoic) supracrustal sequences. VIII - Major structures. Keys: Paleoproterozoic plutons: 1 - Glória quartz-monzodiorite; 2 - Brumado diorite: 3 - Rio Grande diorite; 4 - Rio Grande gabbro; 5 - São Sebastião da Vitória gabbro; 6 - Brito quartz-diorite; 7 - Vitoriano Veloso gabbro; 8 - Ibituruna diorite; 9 -Cassiterita tonalite/trondhjemite; 10 - Tabuões trondhjemite; 11 - Ritápolis granitoid; 12 - Brumado de Baixo granodiorite; 13 Brumado de Cima granodiorite and granophyric bodies; 14 - Tiradentes granitoid; 15 - Nazareno granite; 16 - Itumirim granitoid; 17 - Congonhas tonalite; 18 - Campolide granite; 19 - Ressaquinha complex; 20 - Fé granitic-gneiss; 21 - Alto Maranhão tonalite. Archean plutons: 22 - Caeté granodiorite; 23 - General Carneiro granite; 24 - Morro da Pedra granite; 25 - Ibirité granodiorite; 26 Samambaia tonalite; 27 - Mamona granodiorite; 28 - Salto do Paraopeba granite; 29 - Bom Sucesso granite.

rocks, with rare monzodioritic terms. They are comparable to those of the Brumado (C.A. Ávila, unpublished data), Rio Grande (F.M. Couto, unpublished data) and Ibituruna (Quéméneur et al. 1994) dioritic intrusions. However, the Glória quartz-monzodiorite shows relatively higher K-feldspar content.

Mineralogical transformations of the Glória primary mineralogy were attributed either to an ear- 


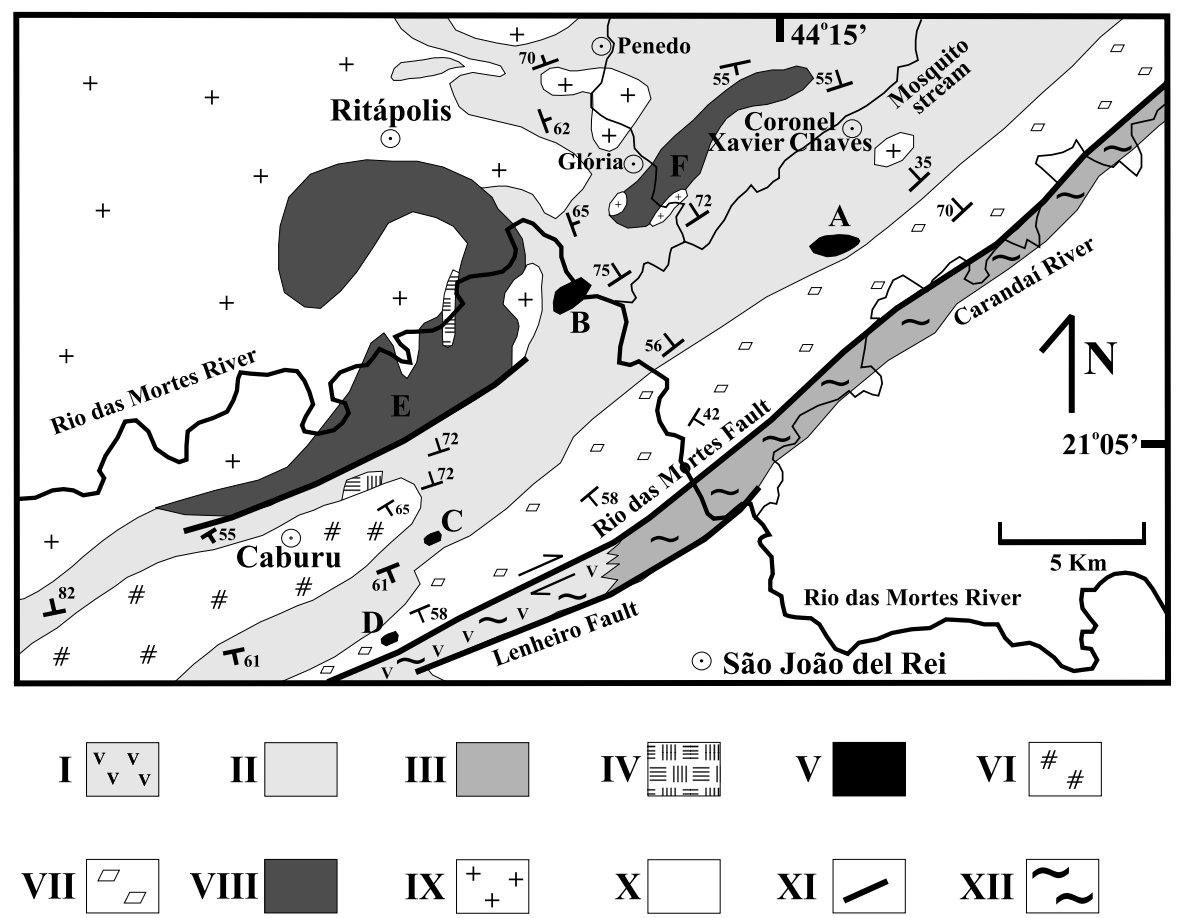

Fig. 2 - Geologic sketch of the region between Ritápolis, São João del Rei and Coronel Xavier Chaves, modified from Ávila et al. (2004). I - Metaultramafic, metapelite and metaquartzite rocks of the Nazareno greenstone belt. II - Amphibolites, metapelites, metaquartzites and gondites of the Rio das Mortes greenstone belt. III - Granitoid (mylonite). IV - Metaultramafic rock. V Pyroxenite/gabbroic bodies (A, B, C, D). VI - Cassiterita tonalite/trondhjemite. VII - Fé granitic-gneiss. VIII - Dioritic/monzodioritic bodies (E: Brumado diorite; F: Glória quartz-monzodiorite). IX - Ritápolis granitoic. X - Proterozoic supracrustal sequences (São João del Rei, Carandaí and Andrelândia). XI - Faults. XII - Lenheiro shear zone, controlled by the Rio das Mortes and Lenheiro faults. The main orientation of the plutons, as well as the network of tectonic structures, reflect the NW trend of the Mineiro belt. See text for details.

lier metamorphism, or to a later local K-metasomatism developed along the contacts between the quartz-monzodiorite and the granitic dykes and apophysis of the Ritápolis granitoid (Ávila et al. 2004). The metamorphic episode originated actinolite, sodic plagioclase, epidote and titanite, forming the mineral assemblage aligned parallel to the regional structural trend of the Mineiro belt (see Figure 2). The metamorphic actinolite was partially replaced by metasomatic biotite and/or chlorite, as observed in both the Glória and Brumado plutons. Such evidence indicates that: i) the metamorphic crystallization occurred during either the pre- or the syntectonic phase of the Mineiro belt; and ii) the Kmetasomatism is younger than the crystallization of the Brumado diorite (2131 $\pm 4 \mathrm{Ma})$ and older or coeval to the Ritápolis dykes and apophyses (2121 \pm $7 \mathrm{Ma})$.

\section{WHOLE ROCK GEOCHEMISTRY}

Whole rock major and trace elements in eleven selected samples of the Glória quartz-monzodiorite were carried out in the laboratories of Lakefield Geosol and X-ray fluorescence of the Federal University of Rio de Janeiro. The main chemical characteristics of the Glória pluton indicate a metaluminous composition, a sub-alkaline trend, and a calcalkaline tendency, with intermediate $\mathrm{K}$ contents (Ávila et al. 2006). 
Major, minor and trace element show significant variation in the recognized facies, allowing some correlation with the crystallization process. The FM facies rock samples shows a restricted variation in $\mathrm{SiO}_{2}$ content (from $57.20 \%$ to $58.81 \%$ ); one sample of the $\mathrm{F}$ facies showed $\mathrm{SiO}_{2}, \mathrm{MgO}, \mathrm{CaO}$ and $\mathrm{Na}_{2} \mathrm{O}$ contents that fit the typical range of the FM facies. On the other hand, the $\mathrm{M}$ facies rock samples show a large variation in $\mathrm{SiO}_{2}$ (from 58.20\% to $64.30 \%$ ), that allowed its separation into two distinct subgroups (M-I and M-II facies). Rocks of the M-I facies are chemically restricted with respect to $\mathrm{SiO}_{2}$ content (58.20\% a 59.22\%), whereas samples of the M-II facies exhibit a larger variation in $\mathrm{SiO}_{2}$ and other oxides $\left(\mathrm{Al}_{2} \mathrm{O}_{3}, \mathrm{MgO}, \mathrm{CaO}\right)$, when compared to the F, FM and M-I facies rocks (Ávila et al. 2006).

The F, FM and M-I facies display strong enrichment in $\mathrm{Sr}$ (which is accompanied by $\mathrm{SiO}_{2}$ increase), contrasting sharply with the depletion of $\mathrm{Sr}$, and also $\mathrm{Ca}$, for the M-II facies rocks (Figure 3). Such chemical features suggest that plagioclase doesn't play an important role during the crystallization of F, FM and M-I facies of the Glória quartzmonzodiorite.

Samples of the FM and M-I facies are characterized by prominent enrichment of LREE with $(\mathrm{La} / \mathrm{Yb})_{\mathrm{n}}$ between 29.66 and 37.96, and weak negative Eu anomalies (Ávila et al. 2006). Data plotted in a spidergram (not shown) suggest a volcanic arc signature, given by the $\mathrm{Nb}$ and Ti negative anomalies and the low content of $\mathrm{Y}$ of the samples. Moreover, positive $\mathrm{Zr}$ and negative $\mathrm{P}$ anomalies are observed and may be interpreted as inheritance from the magma, as suggested also by the relationships between $\mathrm{Rb}$ vs $(\mathrm{Y}+\mathrm{Nb})$, which are characteristic of magmatic arc rocks (Figure 4). However, two of the studied samples plot in the WPG field.

\section{ANALYTICAL TECHNIQUES}

$\mathrm{U}-\mathrm{Th}-\mathrm{Pb}$ isotopic ratios and concentrations of the Glória samples were determined at the Beijing SHRIMP Laboratory of the Chinese Academy of
Geological Sciences, China (Table I). The standard zircon SL13 (572 Ma; ${ }^{206} \mathrm{~Pb} /{ }^{238} \mathrm{U}=0.0928$ ) was used for the inter-element ratio calibrations. The analytical procedures and data assessment followed Stern (1998) and Williams (1998). Grains were mounted in epoxy resin, polished and examined under transmitted and reflected light. Cathodoluminescence microscopy (CL) at the SHRIMP laboratory was used prior to the analyses to allow some additional observation of the zircon's morphology. The Isoplot/EX program (Ludwig 2000) was used for age calculation.

Sm-Nd whole rock analyses were performed at the Geochronological Research Center (CPGeo) of the University of São Paulo, Brazil (Table II). Approximately $0.1 \mathrm{mg}$ of powdered rock sample was dissolved in concentrated $\mathrm{HNO}_{3}, \mathrm{HF}$ and $\mathrm{HCl}$. The $\mathrm{Sm}$ and $\mathrm{Nd}$ concentrations were determined by isotope dilution using a mixed spike and two-column technique (Sato et al. 1995). The isotope ratios were measured on a VG-354 multi-collector mass spectrometer. Laboratory blanks for the chemical procedure, during the period of analyses, yielded maximum values of $0.4 \mathrm{ng}$ for $\mathrm{Nd}$ and $0.7 \mathrm{ng}$ for $\mathrm{Sm}$. The average measurements of ${ }^{143} \mathrm{Nd} /{ }^{144} \mathrm{Nd}$ for the La Jolla international standard was 0.511857 (46) at the $2 \sigma$ level. All the Sm-Nd $\mathrm{T}_{\mathrm{DM}}$ model ages were calculated using DePaolo (1981) and DePaolo et al. (1991) model parameters: $\mathrm{a}=0.25, \mathrm{~b}=-3.0$, $\mathrm{c}=8.5$, as well as ${ }^{146} \mathrm{Nd} /{ }^{144} \mathrm{Nd}=0.7219$ to normalize the isotope ratios $\left[{ }^{143} \mathrm{Nd} /{ }^{144} \mathrm{Nd}=\mathrm{Nd}(\mathrm{CHUR})_{0}\right.$ $=0.512638$ and $\left.{ }^{147} \mathrm{Sm} /{ }^{144} \mathrm{Nd}(\mathrm{CHUR})_{0}=0.1967\right]$. The $\varepsilon_{\mathrm{Nd}(\mathrm{T})}$ values were calculated using the simplified equation $\varepsilon_{\mathrm{Nd}(\mathrm{T})}=\varepsilon_{\mathrm{Nd}(0)}-\mathrm{Q}_{\mathrm{Nd}} \mathrm{f}_{\mathrm{Sm}-\mathrm{Nd}} \mathrm{T}$, with the $(\text { CHUR })_{0}$ values mentioned above and $\mathrm{Q}_{\mathrm{Nd}}=25.09$.

\section{RESULTS AND DISCUSSION}

\section{SHRIMP U-PB GEOCHRONOLOGY}

The analyses were carried out on zircon grains from sample CAWT02 (M-II facies), composed dominantly of amphibole, plagioclase, quartz and biotite, as well as accessory minerals. Among the latter, zircon usually occurs as pink-colored euhedral crystals 


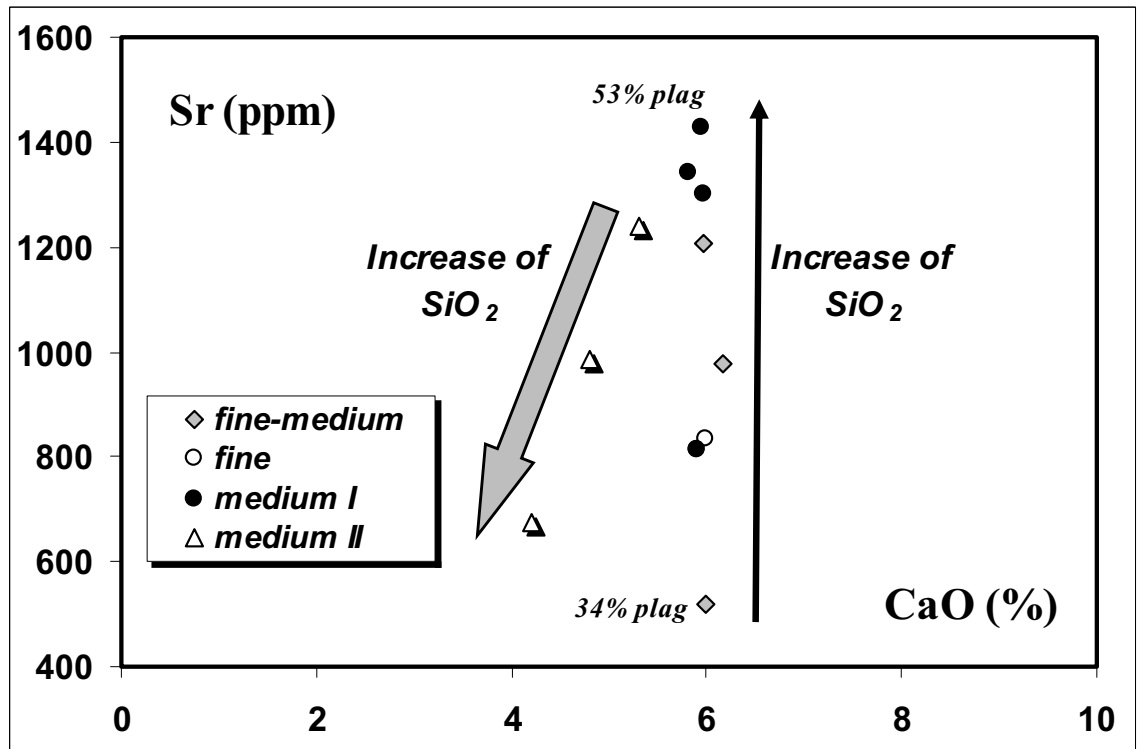

Fig. $3-\mathrm{Sr} \times \mathrm{CaO}$ diagram for the recognized facies rocks of the Glória quartz-monzodiorite.

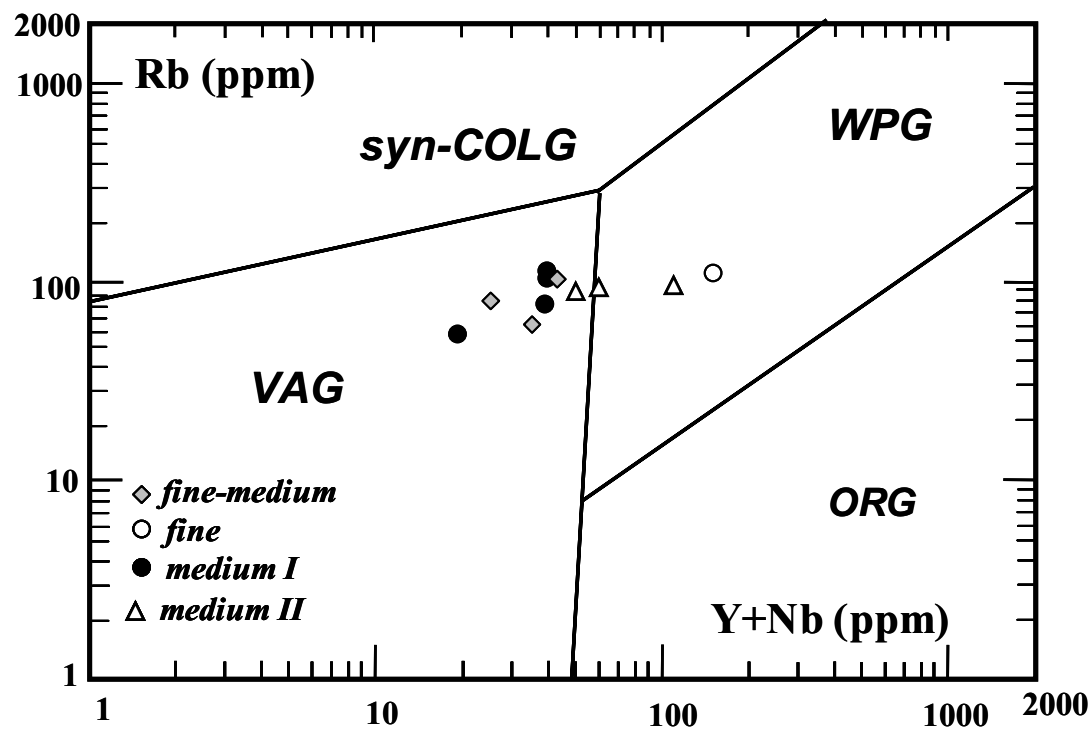

Fig. $4-\mathrm{Rb} \times(\mathrm{Y}+\mathrm{Nb})$ discrimination diagram (Pearce et al. 1984) for selected samples of the Glória quartz-monzodiorite.

with bipyramidal prismatic habit, but with slightly different sizes (Figure 5).

The $\mathrm{U}-\mathrm{Pb}$ analyses were performed in five zircon crystals (Table I), with one of the grains analyzed in two different sites (spots QZD 3.1 and 3.2).
Three quite different ages were obtained (Figure 6). The oldest ${ }^{207} \mathrm{~Pb} /{ }^{206} \mathrm{~Pb}$ age, obtained in the zircon core of the crystal QZD $3.2(2319 \pm 48$ $\mathrm{Ma})$, displays a large error due to radiogenic $\mathrm{Pb}$ loss, and may reflect a minimum estimated age for 
TABLE I

SHRIMP U-Pb data of sample CAWT02 (PC-18E - M-II facies) of the Glória quartzmonzodiorite. The ratios were corrected to common lead $\left({ }^{204} \mathbf{P b}\right)$. See text for details.

\begin{tabular}{c|c|c|c|c|c|c|c|c|c}
\hline Spot & $\begin{array}{c}\mathrm{U} \\
(\mathrm{ppm})\end{array}$ & $\begin{array}{c}\mathrm{Th} \\
(\mathrm{ppm})\end{array}$ & $\mathrm{Th} / \mathrm{U}$ & $\begin{array}{c}\mathrm{Pb} \\
(\mathrm{ppm})\end{array}$ & $\begin{array}{c}{ }^{204} \mathrm{~Pb} \\
(\mathrm{ppb})\end{array}$ & $\begin{array}{c}{ }^{206} \mathrm{~Pb} / \\
{ }^{238} \mathrm{U}^{*}\end{array}$ & error & $\begin{array}{c}{ }^{207} \mathrm{~Pb} / \\
{ }^{235} \mathrm{U}^{*}\end{array}$ & error \\
\hline QZD-1 & 167 & 214 & 1.28 & 81 & 3 & 0.379 & 0.011 & 6.81 & 0.21 \\
\hline QZD-2 & 258 & 316 & 1.22 & 118 & 1 & 0.358 & 0.010 & 6.51 & 0.18 \\
\hline QZD-3.1 & 525 & 67 & 0.13 & 166 & 11 & 0.317 & 0.007 & 5.57 & 0.15 \\
\hline QZD-3.2 & 276 & 275 & 1.00 & 98 & 139 & 0.282 & 0.044 & 5.74 & 0.92 \\
\hline QZD-4 & 277 & 355 & 1.28 & 133 & 4 & 0.372 & 0.006 & 6.88 & 0.15 \\
\hline QZD-5 & 113 & 92 & 0.81 & 47 & 2 & 0.358 & 0.009 & 6.51 & 0.18 \\
\hline
\end{tabular}

TABLE I (continuation)

\begin{tabular}{c|c|c|c|c|c|c}
\hline Spot & ${ }^{207} \mathrm{~Pb} /{ }^{206} \mathrm{~Pb}^{*}$ & error & $\begin{array}{c}\text { Age } \\
206 \mathrm{~Pb} /{ }^{238} \mathrm{U} \\
(\mathrm{Ma})\end{array}$ & $\begin{array}{c}\text { Age } \\
{ }^{207} \mathrm{~Pb} /{ }^{206} \mathrm{~Pb} \\
(\mathrm{Ma})\end{array}$ & $\begin{array}{c}\text { Age } \\
{ }^{207} \mathrm{~Pb} /{ }^{206} \mathrm{~Pb} \\
(\mathrm{Ma})\end{array}$ & $\begin{array}{c}\mathrm{Conc} . \\
(\%)\end{array}$ \\
\hline QZD-1 & 0.1303 & 0.0008 & $2071 \pm 52$ & $2087 \pm 27$ & $2102 \pm 11$ & 99 \\
\hline QZD-2 & 0.1319 & 0.0007 & $1974 \pm 46$ & $2048 \pm 25$ & $2123 \pm 9$ & 93 \\
\hline QZD-3.1 & 0.1275 & 0.0016 & $1775 \pm 35$ & $1912 \pm 24$ & $2064 \pm 22$ & 86 \\
\hline QZD-3.2 & 0.1477 & 0.0041 & $1602 \pm 223$ & $1938 \pm 149$ & $2319 \pm 48$ & 69 \\
\hline QZD-4 & 0.1341 & 0.0015 & $2040 \pm 30$ & $2096 \pm 20$ & $2152 \pm 20$ & 95 \\
\hline QZD-5 & 0.1321 & 0.0013 & $1971 \pm 43$ & $2048 \pm 25$ & $2126 \pm 17$ & 93 \\
\hline
\end{tabular}

*Corrected for ${ }^{204} \mathrm{~Pb}$.

TABLE II

Sm-Nd whole rock analytical data of sample CAWT02 (PC-18E - M-II facies) of Glória quartzmonzodiorite, and of four neighboring plutons. $\left.\varepsilon_{\mathrm{Nd}} \mathrm{T}\right)$ values were calculated according to the crystallization age of the Glória quartz-monzodiorite. See text for details.

\begin{tabular}{c|c|c|c|c|c|c}
\hline SPS & Sample & Rock type & $\mathrm{Sm}(\mathrm{ppm})$ & $\mathrm{Nd}(\mathrm{ppm})$ & ${ }^{147} \mathrm{Sm} /{ }^{144} \mathrm{Nd}$ & ${ }^{143} \mathrm{Nd} /{ }^{144} \mathrm{Nd}$ \\
\hline 2482 & CAWT02 -Glória & Quartz-monzodiorite & 8.02 & 44.94 & $0.1079 \pm 4$ & $0.511195 \pm 12$ \\
\hline 2481 & CAWT01-Fé & Granitic gneisse & 7.28 & 39.84 & $0.1105 \pm 4$ & $0.511245 \pm 13$ \\
\hline 1299 & Geocr-10-Cassiterita & Trondhjemite-tonalite & 2.14 & 12.60 & $0.1031 \pm 3$ & $0.511260 \pm 10$ \\
\hline 1302 & Geocr-7-Brumado & Tonalite-diorite & 4.33 & 19.87 & $0.1318 \pm 5$ & $0.511598 \pm 11$ \\
\hline 1301 & Geocr-5-Ritápolis & Granite & 3.35 & 20.48 & $0.0988 \pm 3$ & $0.511159 \pm 21$ \\
\hline
\end{tabular}

TABLE II (continuation)

\begin{tabular}{c|c|c|c|c|c|c}
\hline SPS & Sample & Rock type & $f_{\text {Sm/Nd }}$ & $\mathrm{T}_{\mathrm{DM}}(\mathrm{Ma})$ & $\varepsilon_{(0)}$ & $\varepsilon_{(2.0 \mathrm{Ga})}$ \\
\hline 2482 & CAWT02 -Glória & Quartz-monzodiorite & -0.45 & 2.68 & -28.1 & -5.5 \\
\hline 2481 & CAWT01-Fé & Granitic gneisse & -0.44 & 2.68 & -27.2 & -5.2 \\
\hline 1299 & Geocr-10-Cassiterita & Trondhjemite-tonalite & -0.48 & 2.47 & -26.9 & -3.0 \\
\hline 1302 & Geocr-7-Brumado & Tonalite-diorite & -0.33 & 2.72 & -20.3 & -3.7 \\
\hline 1301 & Geocr-5-Ritápolis & Granite & -0.50 & 2.51 & -28.8 & -3.9 \\
\hline
\end{tabular}



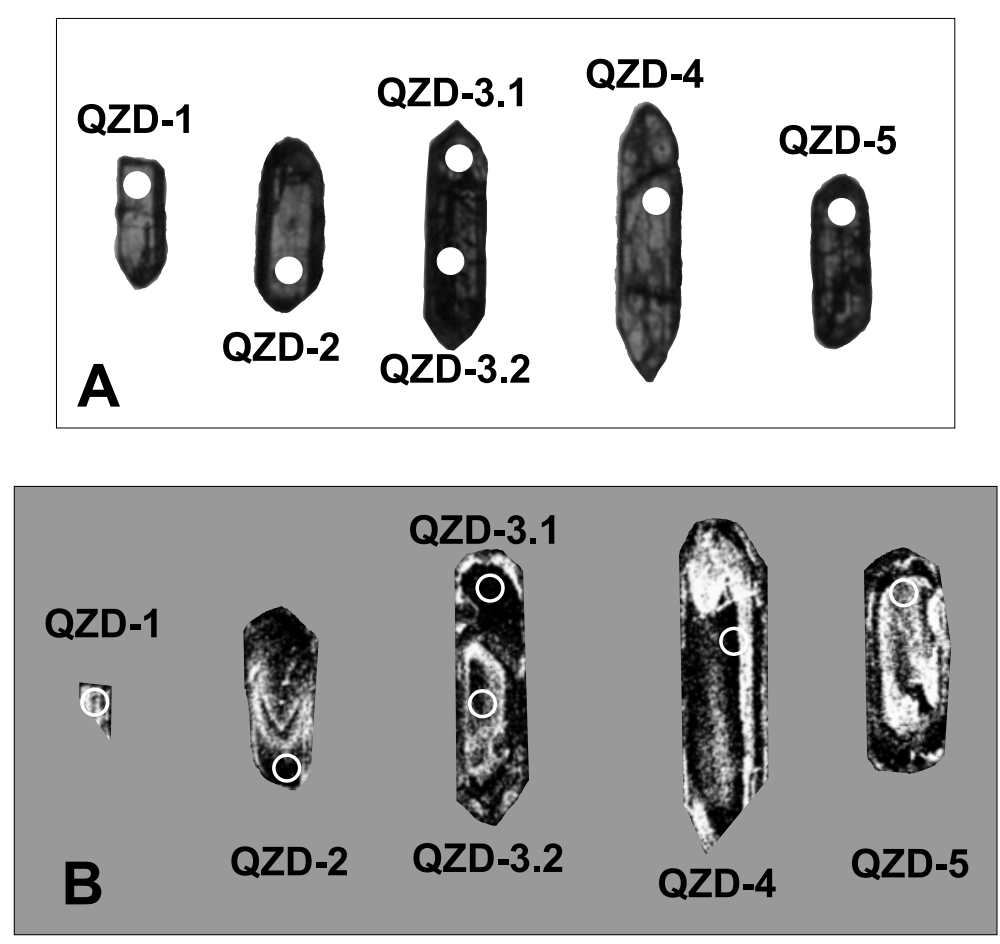

Fig. 5 - Microscope (A) and cathodoluminescense (B) images of zircon grains from sample CAWT02 (PC-18E - M-II facies) of Glória quartz-monzodiorite.

the crustal protholith. Tentatively, this apparent age is broadly comparable to the ${ }^{207} \mathrm{~Pb} /{ }^{206} \mathrm{~Pb}$ ages reported by Machado et al. (1996) in detritic zircon grains from the Sabará metasedimentary sequence in the Quadrilátero Ferrífero region. Such sequence is genetically related to foreland basin deposits produced by erosion of the Archean and Paleoproterozoic basement of the São Francisco Craton.

Four analyses (spots QZD 2, 3.1, 4, 5) provided an upper intercept age of $2188 \pm 29$ Ma in the Concordia, here interpreted as the best estimate for the crystallization age of the Glória quartz-monzodiorite.

On the other hand, the discordia lower intercept might reflect a Neoproterozoic overprint (ca. $790 \mathrm{Ma}$ ), consistent with the polycyclic geologic setting of the marginal domain of the São Francisco Craton, that includes well recognized Neoproterozoic events, given by several K-Ar apparent ages between 740-540 Ma (biotite and amphibole) from the country rocks (e.g., Teixeira 1982, Teixeira and Canzian 1996, Teixeira et al. 2000). Moreover, the São João del Rei, Carandaí and Andrelândia supracrustal sequences underwent greenschist facies metamorphism, dated at 570 Ma by Söllner and Trouw (1997).

The youngest U-Pb age spot QZD 1 (2102 士 $8 \mathrm{Ma}$ ) is concordant (see Figure 6). Whereas this age may be related to a late tectonic episode, its geologic significance is still a matter of debate, as supported by field observations and geochronology (e.g., Ritápolis dykes dated at 2121 Ma crosscut the Glória pluton and the metamorphism is significantly older: 2131-2121 Ma - see above).

Several bodies that occur in the vicinity of the Glória pluton were emplaced contemporaneously with it, as evidenced by their U-Pb and ${ }^{207} \mathrm{~Pb}-{ }^{206} \mathrm{~Pb}$ ages (see location in Figure 1): São Sebastião da Vitória gabbro (2220 $\pm 3 \mathrm{Ma}$ ), Cassiterita tonalite/ trondhjemite (2162 $\pm 10 \mathrm{Ma})$, Rio Grande diorite 


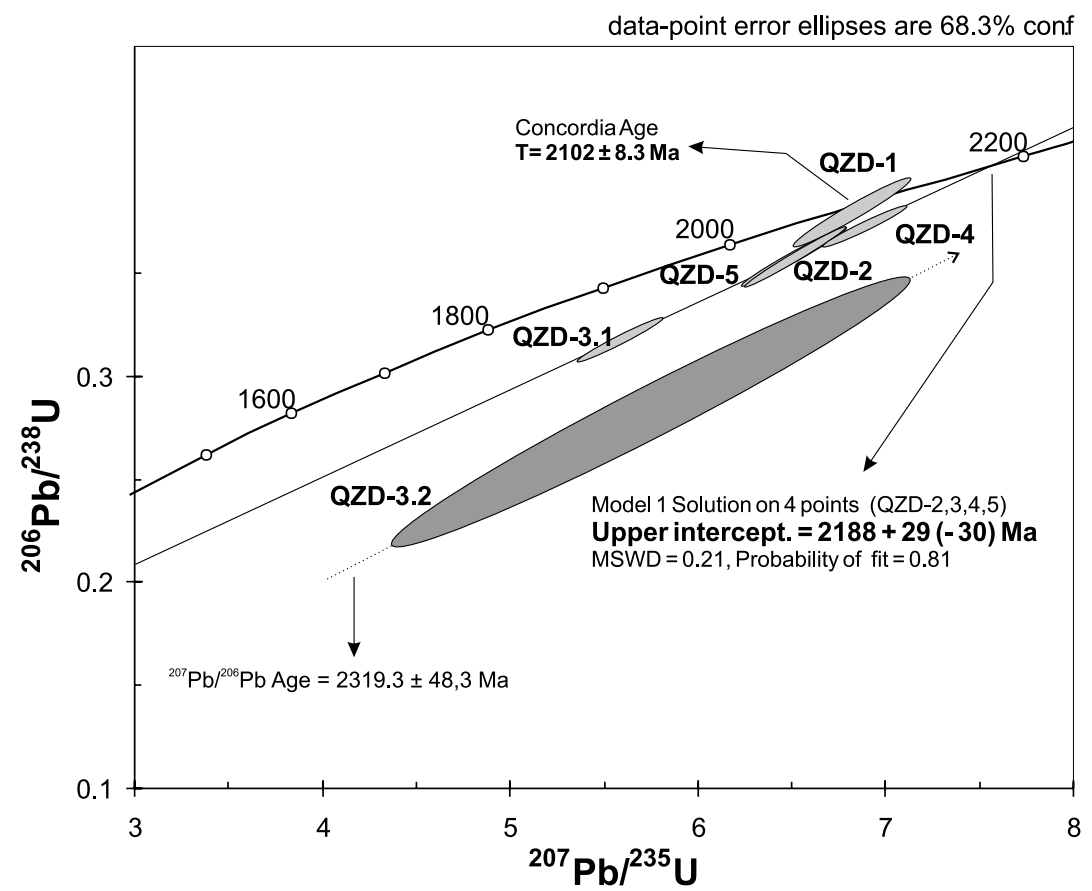

Fig. 6 - SHRIMP U-Pb diagram of sample CAWT02 (PC-18E - M-II facies) of the Glória quartz-monzodiorite. See text for details.

$(2155 \pm 3 \mathrm{Ma})$ and Brumado diorite $(2131 \pm 4 \mathrm{Ma})$ -(Valença et al. 2000, Ávila et al. 2003, C.A. Ávila, unpublished data, A.F. Cherman, unpublished data). Such age range (2220-2130 Ma) may indicate the overall duration of magmatic evolution within this segment of the Mineiro belt. Moreover, all of these bodies are older than the plutons of the belt outcropping toward east, in the Conselheiro Lafaiete region (see Figure 1), such as the Alto Maranhão batholith. This pluton is interpreted as pre-collisional (Noce et al. 2000) and yields concordant U-Pb ages (zircon, titanite) of $2124 \pm 2$ Ma.

The emplacement of the Alto Maranhão batholith is roughly contemporary with the Itumirim (2101 $\pm 8 \mathrm{Ma}$; see Figure 1) and Macuco de Minas $(2116 \pm 9 \mathrm{Ma}$; not shown) granitoids (A.F. Cherman, unpublished data), that outcrop in the region between Lavras and São João del Rei towns. These intrusions are linked with the final magmatic stage in the central part of the Mineiro belt, in a similar way to the Ritápolis dykes and apophyses (2121士
$7 \mathrm{Ma}$ ) that crosscut the Glória quartz-monzodiorite (Ávila et al. 2004).

\section{SM-ND ISOTOPES}

The Sm-Nd isotopic data of sample CAWT02 are presented in Table II together with the unpublished analyses of four neighboring plutons that crop out to the north of the Lenheiro shear zone (Cassiterita, Brumado, Fé, Ritápolis plutons; see Figure 2). The samples show $f \mathrm{Sm} / \mathrm{Nd}$ values $(-0.50$ to -0.33$) \mathrm{com}$ patible with crustal parameters for $\mathrm{Nd}$ fractionation and calculated $\mathrm{Sm}-\mathrm{Nd} \mathrm{T}_{\mathrm{DM}}$ (single) model ages of 2.5 to $2.7 \mathrm{Ga}$. One of the samples (1302), with the highest $f \mathrm{Sm} / \mathrm{Nd}$ value (calculated double-stage TDM model age is $2.56 \mathrm{Ga}$ ) might be slightly fractionated. All samples show different negative $\varepsilon_{\mathrm{Nd}(2.0 \mathrm{Ga})}$ values (-3.0 to -5.5$)$, and therefore significant differences in their sources may be envisaged.

The Glória quartz-monzodiorite (sample CAWT02) and Fé granitic-gneiss (sample CAWT01) display quite similar isotopic parameters $\left(\mathrm{T}_{\mathrm{DM}}=\right.$ 
$2.7 \mathrm{Ga}$ and $\varepsilon_{\mathrm{Nd}(2.0 \mathrm{Ga})}=-5.5$ to -5.2$)$, whereas the Brumado, Cassiterita and Ritápolis plutons show lower negative values $\left(\varepsilon_{\mathrm{Nd}(2.0 \mathrm{Ga})}=-3.0\right.$ to -3.9$)$. As such, the $\mathrm{Nd}$ isotopic evidence suggests that the $\mathrm{Pa}$ leoproterozoic juvenile magmas were contaminated in different proportions by older crustal material, either Archean protholiths, or supracrustal material from the neighboring greenstone belts. In any case, subordinate remelting of the Archean crust in the magma-genesis cannot be excluded, as suggested from the oldest $\mathrm{T}_{\mathrm{DM}}$ ages.

Considering the Mineiro belt at the regional scale, these plutons show $\varepsilon_{\mathrm{Nd}(\mathrm{T})}$ signatures consistent with the isotopic characteristics and chemistry of both "Group A" and "Group B" granitoids of the Mineiro belt (Noce et al. 2000) (Table III). According to this classification, "Group A" plutons (e.g. Porto Mendes, Ritápolis, Itutinga and Alto Jacarandá; see Figure 1) are dominantly peraluminous, yield $\mathrm{T}_{\mathrm{DM}}$ values between 2.6-2.8 Ga, and show more negative $\varepsilon_{\mathrm{Nd}(\mathrm{T})}$ values than "Group B" granitoids. "Group B" plutons (e.g., Alto Maranhão and Tabuões) include metaluminous rocks and show $\mathrm{T}_{\mathrm{DM}}$ model ages between 2.3 and $2.5 \mathrm{Ga}$. The subdivision envisaged by Noce et al. (2000) is strongly dependent on $\mathrm{Rb} / \mathrm{Sr}$ geochronology (except for the Alto Maranhão batholith), and needs to be better constrained by additional U-Pb ages in the light of the new data herein presented. In any case, although both plutons are metaluminous, the Alto Maranhão batholith is significantly younger (2124 Ma) than the Glória quartz-monzodiorite (2188 Ma).

Figure 7 presents the $\mathrm{Nd}$ signatures of the granitoids of the Mineiro belt in conjunction with data from the Glória quartz-monzodiorite and other coeval pre-collisional plutons of the central part of the belt (Brumado, Rio Grande, Cassiterita). On the basis of data distribution, the "Group A" plutons clearly exhibit a major role of contamination of Archean components in the magma source. Conversely, most of the samples of the pre-collisional plutons (see above) plot in the "B Group" field (Noce et al. 2000). These samples exhibit more negative
$\varepsilon_{\mathrm{Nd}(\mathrm{T})}$ values than the signature of the Paleoproterozoic mafic dykes genetically related to the evolution of the Paleoproterozoic belt. The characteristic negative isotopic signature of these samples also contrasts with that of the Alto Maranhão batholith (pre-collisional) which crops out in the eastern part of the belt. Particularly the Glória quartz-monzodiorite, although showing a metaluminous chemistry, exhibit a $\varepsilon_{\mathrm{Nd}(\mathrm{T})}$ signature compatible with "Group A" rather than that of "Group B" plutons.

The data plotted in Figure 7 demonstrate the genetic differences among the pre-collisional magmas due to smaller degree of contamination of the source (even for the Gloria pluton), when compared with the $\varepsilon_{\mathrm{Nd}(\mathrm{T})}$ variation interval of the Archean basement. The Nd evolution of these plutons from 2.18 Ga (Glória emplacement age) to $2.12 \mathrm{Ga}$ (Alto Maranhão emplacement age) reveals that the pre-collisional stage in the São João del Rei region (west) is older than in Lafaiete region (east). In addition, the role of tectonic and magmatic migration from west to east is also apparent.

\section{FINAL REMARKS}

The primary mineralogical assemblage of the Glória quartz-monzodiorite was partly modified by metamorphism, as shown by the formation of minerals typical of greenschist to low-amphibolite facies. Such a metamorphic overprint, commonly recorded in other contemporary plutons of the Mineiro belt (São Sebastião da Vitória gabbro, Brumado and Rio Grande diorites, Cassiterita tonalite/ trondhjemite) is widespread in the São João del Rei region. Particularly, the growth of metasomatic biotite over actinolite along the margins of dykes and granitic apophyses, as observed in the Glória quartz-monzodiorite and Brumado diorite, constrain the time of the K-metasomatism. This episode is somewhat younger than the crystallization age of the Brumado diorite (2131 $\pm 4 \mathrm{Ma})$ and older or contemporary to the Ritápolis granitoid (2121 \pm $7 \mathrm{Ma})$.

From the Nd isotopic perspective, the genera- 


\section{TABLE III}

Summary of the geochronological and Nd-Sr data of plutonic bodies of the Mineiro belt. The T $T_{D M}$ ages were calculated according to De Paolo et al. (1981). Keys: A - U-Pb isotopic dilution (zircon and sphene); $\mathbf{B}-{ }^{207} \mathbf{P b} /{ }^{206} \mathbf{P b}$ (Pb evaporation on zircon); $\mathbf{C}-\mathbf{R b} / \mathbf{S r}$ (whole rock isochron); Ref. (1 - A.F. Cherman, unpublished data; 2 - Noce et al. 2000). Sr and Nd isotopic data were calculated for $\mathrm{T}=2.0 \mathrm{Ga}$.

\begin{tabular}{|c|c|c|c|c|c|c|}
\hline Plutons & Lithology & $\varepsilon_{\mathrm{Nd}(\mathrm{t}=2.0 \mathrm{Ga})}$ & $\varepsilon_{\mathrm{Nd}(\mathrm{t})}$ & $\varepsilon_{\mathrm{Nd}(0)}$ & $\mathrm{T}_{\mathrm{DM}(\mathrm{Ma})}$ & Ref. \\
\hline \multirow{2}{*}{ Itumirim } & Gneiss & -1.9 & -0.1 & -20.0 & 2.49 & 1 \\
\hline & Granite & -4.5 & -2.9 & -30.8 & 2.53 & 1 \\
\hline Rio Grande & Diorite & -2.7 & -0.8 & -24.3 & 2.49 & 1 \\
\hline Alto Maranhão & Tonalite & -0.2 & +1.3 & -23.2 & 2.27 & 2 \\
\hline \multirow{3}{*}{ Porto Mendes } & \multirow{3}{*}{ Granite } & -5.7 & -4.9 & -31.3 & 2.62 & 2 \\
\hline & & -11.8 & -11.0 & -38.1 & 3.03 & 2 \\
\hline & & -10.8 & -10.3 & -27.9 & 3.40 & 2 \\
\hline Ressaquinha & Granite-tonalite & -1.5 & -1.3 & -31.1 & 2.30 & 2 \\
\hline Lavras & Granite & -6.3 & -3.8 & -28.6 & 2.48 & 2 \\
\hline Tabuões & Trondhjemite & -2.3 & -2.8 & -25.5 & 2.43 & 2 \\
\hline \multirow{2}{*}{ Alto Jacarandá } & \multirow{2}{*}{ Granite } & -6.6 & -7.6 & -26.7 & 2.85 & 2 \\
\hline & & -9.6 & -10.8 & -33.4 & 2.95 & 2 \\
\hline \multirow{2}{*}{ Ritápolis } & \multirow{2}{*}{ Granite } & -5.4 & -5.9 & -13.7 & 2.62 & 2 \\
\hline & & -6.4 & -7.3 & -18.4 & 2.71 & 2 \\
\hline \multirow{2}{*}{ Itutinga } & Gneiss & -3.4 & -1.1 & -24.7 & 2.56 & 1 \\
\hline & Granite & -7.2 & -7.7 & -17.5 & 2.77 & 2 \\
\hline
\end{tabular}

tion of the Mineiro belt plutonism in the Lavras São João del Rei region involves mixtures of Paleoproterozoic juvenile components and subordinately Archean crustal material. The Glória quartz-monzodiorite shows $\mathrm{Sm}-\mathrm{Nd}$ isotopic values significantly different from those of the more mafic plutonic terms of the Mineiro belt. Its signature is probably influenced by a metasedimentary component (phyllites, banded gneisses, biotite-muscovite schists) of the surrounding Rio das Mortes greenstone belt, as suggested from field relations. On the other hand, the Archean protoliths comprise medium- to high-grade metamorphic rocks of the southern São Francisco Craton (from Archean metamorphic complexes).

The field and geochronological evidence together with the calc-alkaline characteristics of the
Glória pluton, indicate its genetic association with nearby pre-collisional plutons of the Mineiro belt: $2188 \pm 29$ Ma (Glória quartz-monzodiorite); 2162 $\pm 10 \mathrm{Ma}$ (Cassiterita tonalite/trondhjemite); 2155 $\pm 3 \mathrm{Ma}$ (Rio Grande diorite) and $2131 \pm 4 \mathrm{Ma}$ (Brumado diorite). The pre-collisional phase in the central part of the Mineiro belt took place before 2131 Ma ago. In contrast, the Alto Maranhão precollisional pluton in the Conselheiro Lafaiete area is dated at $2124 \pm 2$ Ma. A particular tectonic polarity is therefore revealed for the evolution of the magmatism within the Mineiro belt.

Finally, taking into account the metamorphic ages reported in the lithotectonic units related to the belt, there are also some significant time difference between the São João del Rei (west) and 


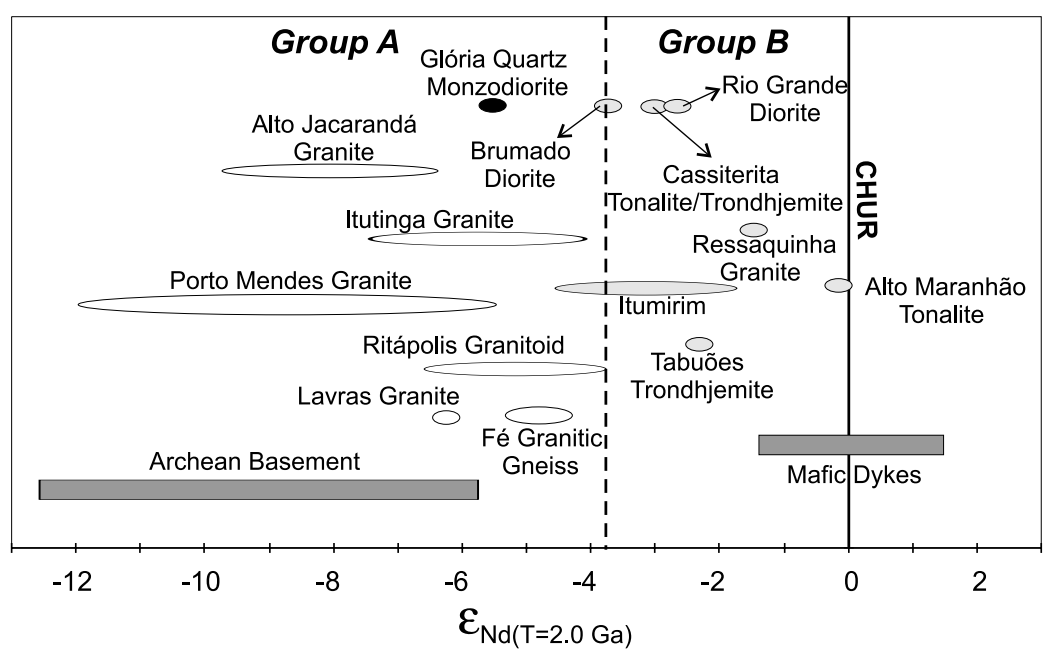

Fig. 7 - Isotopic characteristics $[\varepsilon \mathrm{Nd}(\mathrm{T})$. Reference Time $=2.0]$ of the Mineiro belt plutonic intrusions, Archean country rocks and mafic dykes (adapted from Noce et al. 2000), assuming a homogeneous isotopic evolution at the reference time for the oldest Paleoproterozoic plutons, as well as for the Archean crust. Data compilation from the Archean basement and Paleoproterozoic mafic dykes are also shown (J.P.P. Pinese, unpublished data, Carneiro et al. 1998, Teixeira et al. 1998, Campos et al. 2003).

Lafaiete (east) segments. The metamorphic ages determined for plutonic bodies in the region between Lavras and São João del Rei towns are between 2131-2121 Ma (Ávila et al. 2006). In contrast, much younger $\mathrm{U}-\mathrm{Pb}$ metamorphic ages, between $2059 \pm 6 \mathrm{Ma}$ and $2041 \pm 5 \mathrm{Ma}$, were interpreted by Machado et al. (1996) as related to the metamorphic overprint in the Bação and Belo Horizonte complexes (see Figure 1) in Quadrilátero Ferrífero area. Consequently, it seems that the time of the greenschist- to low-grade amphibolite metamorphism in the region between Lavras and São João del Rei preceded by some 60 Ma the metamorphic overprint in the Quadrilátero Ferrífero region. We speculate that such age difference indicates a migration of the magmatic arc axis of the Mineiro belt from west to east as part of the subduction and crustal shortening processes.

\section{ACKNOWLEDGMENTS}

The authors express special thanks to Paulo Roberto dal Cere for his participation on the preliminary studies and to Joel Valença, André Ribeiro, Fabio
Paciullo and Rudolph Trouw for their support during fieldwork. Ciro Ávila is grateful to Fundação Carlos Chagas Filho de Amparo à Pesquisa do Estado do Rio de Janeiro (FAPERJ), firstly for the grant that supported this study (\# 170.023/2003) and secondly for the associated research fellowship granted to Héctor Barrueto (\# 152.564/2002). Umberto Cordani and Wilson Teixeira acknowledge the support received from the Financiadora de Estudos e Projetos/Programa de Apoio de Núcleos de Excelência (FINEP/PRONEX) (grant 662167/1996-1). Wilson Teixeira and Ciro Ávila thank the Brazilian Research Council for Science and Technology for financial support (grants 304300/03-9; 475673/ 04-2).

\section{RESUMO}

O Quartzo Monzodiorito Glória é um corpo plutônico máfico associado à evolução Paleoproterozóica do Cinturão Mineiro. Este é intrusivo em gnaisses bandados, anfibolitos, xistos e filitos do Greenstone Belt Rio das Mortes, na porção sudeste do Cráton São Francisco, Estado de Minas Gerais, Brasil. Este corpo possui idade 
de cristalização SHRIMP (em zircão) de $2188 \pm 29$ Ma, enquanto os isótopos de $\mathrm{Nd}\left(\varepsilon_{\mathrm{Nd}(\mathrm{T})}=-3,4 ; \mathrm{T}_{\mathrm{DM}}=\right.$ 2,68 Ga) apontam que sua fonte magmática envolveu material juvenil paleoproterozóico contaminada por protólitos arqueanos. As rochas do Quartzo Monzodiorito Glória são metaluminosas, cálcio-alcalinas de médio $\mathrm{K}$ e apresentam características geoquímicas assemelhadas com representantes de arco vulcânico. Em termos geocronológicos o pluton Glória relaciona-se ao estágio précolisional na região central do Cinturão Mineiro, sendo mais antigo que plutons com características químicas semelhantes que ocorrem no Quadrilátero Ferrífero. Sua mineralogia primária foi parcialmente substituída por minerais metamórficos, relacionados a um evento datado entre 2131-2121 Ma. Esse episódio é significantemente mais antigo que o evento metamórfico registrado em granitóides do Cinturão Mineiro no Quadrilátero Ferrífero, ali datado entre 2059-2041 Ma. A integração do conjunto de idades radiométricas $\left(\mathrm{U} / \mathrm{Pb}\right.$ e $\left.{ }^{207} \mathrm{~Pb} /{ }^{206} \mathrm{~Pb}\right)$, dados geoquímicos e isotópicos de corpos plutônicos máficos e félsicos Paleoproterozóicos, relacionados ao estágio pré-colisional do Cinturão Mineiro, sugere a migração tectônica do arco magmático de oeste para leste.

Palavras-chave: Quartzo Monzodiorito Glória, idade U-Pb SHRIMP, isótopos de Sm-Nd, Cinturão Mineiro, Cráton São Francisco.

\section{REFERENCES}

Ávila CA, Valença JG, Neto AA And Couto FM. 1999. Geologia e petrografia de rochas piroxeníticas-gabróicas Arqueanas/Paleoproterozóicas da borda sul do Cráton do São Francisco. Bol Mus Nac, Nova Serie, Geol 50: 1-30.

Ávila CA, Valença JG, Moura CAV, Klein VC AND PEREIRA RM. 2003. Geoquímica e idade do Trondhjemito Cassiterita, borda meridional do Cráton São Francisco, Minas Gerais. Arq Mus Nac 61: $267-284$.

Ávila CA, Teixeira W and Pereira RM. 2004. Geologia e petrografia do Quartzo Monzodiorito Glória, Cinturão Mineiro, porção sul do Craton São Francisco, Minas Gerais. Arq Mus Nac 62: 83-98.

Ávila CA, TeIXeira W, BARrueto HR AND PEREIRA RM. 2006. Geochemistry of the Glória quartz-monzodiorite: implications of dioritic magmatism in the Paleoproterozoic evolution of the southern sector of the Mineiro Belt, Minas Gerais State, Brazil. Arq Mus Nac 64: 73-92.

CAMpos JCS, CARnEIRO MA AND BASEI MAS. 2003. U-Pb evidence for late Neoarchean crustal reworking in the southern São Francisco cráton (Minas Gerais, Brazil). An Acad Bras Cienc 75: 497-511.

CARneiro MA, Teixeira W, CARVAlho Júnior IM AND FERNANDES RA. 1998. Ensialic tectonic setting of the Archean Rio das Velhas Greenstone Belt: $\mathrm{Nd}$ and $\mathrm{Pb}$ isotopic evidence from the Bonfim Metamorphic complex, Quadrilátero Ferrífero. Rev Bras Geo 28: 189-200.

DePaolo DJ. 1981. Nd isotopic studies; some new perspective on Earth structure and evolution. Transactions of Amer Geophys Union 62: 137-140.

DePaolo DJ, Linn AM And Schubert G. 1991. The continental crustal age distribution; methods of determining mantle separation ages from $\mathrm{Sm}-\mathrm{Nd}$ isotopic data and application to the Southwestern United States. J Geophys Res B 96: 2071-2088.

LUDWIG KR. 2000. Isoplot 3.0: A Geochronological Toolkit for Microsoft Excel. Berkeley Geochronology Center Special Publication 4: 71.

Machado N, Schrank A, Noce CM and GaUTHIER G. 1996. Ages of detrital zircon from Archean-Paleoproterozoic sequences: implications for Greenstone Belt setting and evolution of a transamazonian foreland basin in Quadrilátero Ferrífero, southeast Brazil. Earth Plan Sci Lett 141: 259-276.

Noce CM, Teixeira W, Quéméneur JJG, MarTINS VTS AND BOLZACHINI E. 2000. Isotopic signatures of paleoproterozoic granitoids from the southern São Francisco Craton and implications for the evolution of the Transamazonian Orogeny. J South Am Earth Sci 13: 225-239.

PeArCe JA, Harris NBW AND Tindle AG. 1984. Trace element discrimination diagrams for the tectonic interpretation of granitic rocks. J Petrol 25: 956-983.

QuÉmÉneur JJG AND Noce CM. 2000. Geochemistry and petrology of felsic and mafic suites related to the Paleoproterozoic Transamazonian orogeny in Minas Gerais, Brazil. Rev Bras Geoc 30: 87-90.

QuÉmÉneur JJG, Noce CM ANd GARCIA D. 1994. Caracterização das suítes granitóides do arco mag- 
mático transamazônico na borda meridional do Craton do São Francisco, Minas Gerais. In: CongreSso Brasileiro Geologia 38, Bol Res Exp, Camboriú, SC, Brasil 1: 117-119.

Sato K, Tassinari CCG, Kawashita K And PeTRONILHO L. 1995. O Método Geocronológico Sm-Nd no IG/USP e suas aplicações. An Acad Bras Cienc 67: 313-336.

Söllner F AND TROUW RAJ. 1997. The Andrelandia depositional cycle (Minas Gerais/Brazil), a posttransamazonic sequence south of the São Francisco Craton: evidence from $\mathrm{U}-\mathrm{Pb}$ dating of a metasediment. J South Am Earth Sci 10: 21-28.

STERN RA. 1998. High-resolution sims determination of radiogenic trace-isotopic ratios in minerals. Mineralogical association of Canada. Short Course Series 27: 241-268.

TeIXeIRA W. 1982. Geochronology of Southern Part of the São Francisco Cráton. Rev Bras Geoc 12: 268-277.

TeiXeira W And CAnZIAn FS. 1996. A evolução tectonotermal proterozóica do Craton do São Francisco, com base em interpretações geocronológicas $\mathrm{K}-\mathrm{Ar}$ em rochas de seu embasamento. USP, SP, Brasil. Bol Inst Geoc 25: 61-80.

Teixeira W, Cordani UG, Nutman AP and Sato K. 1998. Polyphase Archean evolution in the Campo Belo metamorphic complex, southern São Francisco Craton, Brazil. SHRIMP U-Pb zircon evidence. J South Am Earth Sc 11: 279-289
TeIXeIRA W, SABaté P, BARbosa J, Noce CM AND CARneIro MA. 2000. Archean and Paleoproterozoic evolution of the São Francisco Craton. In: CORDani UG, Millani EJ, Thomaz Filho A And CAmpos DA (Eds), $31^{\text {st }}$ International Geological Congress, Rio de Janeiro, RJ, Brazil, Tectonic Evolution of South América, p. 101-138.

Teixeira W, Ávila CA, Cordani UG, Martins VTS AND VALEnÇA J. 2005. Dados isotópicos $(\mathrm{U} / \mathrm{Pb}, \mathrm{Pb} / \mathrm{Pb}, \mathrm{Sm} / \mathrm{Nd}, \mathrm{Rb} / \mathrm{Sr})$ do plutonismo Paleoproterozóico do Cinturão Mineiro, porção meridional do Cráton São Francisco: implicações tectônicas. In: Simpósio do CRÁton SÃo FrANCISCO 3, Salvador, BA, Brasil, p. 174-177.

VAlençA JG, Silva JG, SchimitT RS, Trouw RAJ AND NoCE CM. 2000. Transamazonian gabbronoritic intrusive rocks from the southernmost São Francisco Craton (Brazil). In: International GeOLogical Congress 31, Sociedade Brasileira de Geologia Rio de Janeiro, RJ, Brazil (Published in CD-ROOM).

WILLIAMS IS. 1998. U-Th-Pb geochronology by ion microprobe. In: MCKIBBEN MA (Ed), Applications of Microanalytival Techniques to Understanding Mineralizing Processes, Economic Geologists Short Course, p. 1-35. 